\title{
The Inner Seas in Deirdre of the Sorrows by John Millington Synge (1909)
}

Les

mers intérieures dans Deirdre des douleurs de John Millington Synge (1909)

\section{Céline Savatier-Lahondès}

\section{OpenEdition}

Journals

Electronic version

URL: http://journals.openedition.org/etudesecossaises/1207

ISSN: 1969-6337

\section{Publisher}

UGA Éditions/Université Grenoble Alpes

Printed version

ISBN: 978-2-37747-001-3

ISSN: 1240-1439

\section{Electronic reference}

Céline Savatier-Lahondès, " The Inner Seas in Deirdre of the Sorrows by John Millington Synge (1909) », Études écossaises [Online], 19 | 2017, Online since 01 April 2017, connection on 08 September 2020.

URL : http://journals.openedition.org/etudesecossaises/1207

\footnotetext{
This text was automatically generated on 8 September 2020

(c) Études écossaises
} 


\title{
The Inner Seas in Deirdre of the Sorrows by John Millington Synge (1909)
}

Les

mers intérieures dans Deirdre des douleurs de John Millington Synge (1909)

\author{
Céline Savatier-Lahondès
}

1 The story of Deirdre ${ }^{1}$ (Dare-dra ${ }^{2}$ or deer-dree, according the Irish or Scottish pronunciations), is part of the Irish Cycle of Ulster, in which the high deeds of the famous hero Cuchulainn are told. Entitled Longes mac nUisna (Uish'na $\left.{ }^{3}\right)-T h e$ Exile of the Sons of Usnagh, it became part of what 18th century manuscripts used to compile as Trí

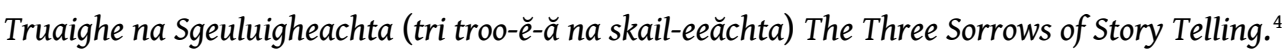
Beside Longes mac nUisna, Oidheadh Chloinne Tuireann (Tirran)-The Tragic Fate of the Children of Tuireann, and Oidheadh Chloinne Lir-The Tragic Fate of the Children of Lir also belong to the Three Sorrows cycle. However, according to Douglas Hyde, who rewrote the tales from the original manuscripts in 1887: "Of the three stories, [...] the Fate of the Children of Usnach is by far the most renowed and widely known [...]."

Deirdre's tale is a story of travel from Ireland to Scotland and back to Ireland after seven years of exile. From Emain Macha (Evin Vaha ${ }^{6}$ ) to Slieve Fuadh (Sleeve Foo' $a^{7}$ ) and to their Scottish refuge, the characters will live their lives fully and decide to face their inescapable tragic fate. In his preface to Deirdre, variations sur un mythe celtique, René Agostini stresses one of the differences between Greek and "Celtic" tragic heroes, stating that in a classic tragedy, the main character struggles to avoid his fate whereas the "Celtic" one is determined to embrace it: "Le héros tragique grec se perd précisément en s'efforçant d'échapper à un déterminisme auquel il ne peut se soustraire, parce qu'il le hante et le suit. Le héros celtique met d'autant plus de fougue et de détermination à ce qu'il vit, à ce qu'il fait, quand il sait ou qu'il devine que c'est sa destinée. Deirdre va au devant de sa destinée, elle la 'provoque."'" (1992, p. 22) Synge fully develops the theme of fate in his play, which adds a philosophical aspect to the original myth. The author questions Man's existence. He questions meaning too, in the awakening of the modern era, at a time when Ireland is 
on its way toward independence, when the revival of the Irish culture is strongly felt in the Irish artistic expression.

Our thesis here is that the inner seas motif plays an important part in this questioning.

In a first part, the accent will be put on geographical considerations as far as texts and territories are concerned. This will enable us to seize the mythic dimension of the tale and to define the space devoted to the inner seas in the play. Then, we will turn to the authorial mapping of the tale which will lead us on both sides of the marine territory under study. Inseparable from this is the political aspect which remains constantly interlaced in the history of the modern rewritings of Deirdre's story. Our last part will lay the emphasis on the sea motif proper, showing how its apparently remote presence swells, until it produces a resounding echo which gives its proportions to the tragedy.

5 The original manuscripts for the story of Deirdre are, for the most ancient ones, the 12th century Book of Leinster 9 and the 14th century Yellow Book of Lecan. They are both Irish manuscripts kept in Trinity College in Dublin. There is also a 15th century Gaelic manuscript kept in Edinburgh, the Glenmasan MS. ${ }^{10}$ Therefore, manuscripts of the text are kept both in Ireland and Scotland. Both countries take their share in the same literary tradition, as Professor Mackinnon stated in the 1904 Celtic Review: "The Tale of the Sons of Uisnech was well known in the Scottish Highlands as in Ireland from time immemorial. It was early committed to writing. It was one of the 'principal tales,' primscela, which a poet must know." (p.6) The oral poetic tradition was one of the major features of Gaelic society. The filidh (or file)-the specialized class of poetsprophets-worked with and transmitted an important corpus of tales, an "elitist" oral literature, according to Professor Proinsias Mac Cana (1997, p. 674). The process of oral transmission dated back long before the stories were transcribed on paper. This cultural phenomenon lasted until the Renaissance period which saw the coexistence of two systems-the literate and the oral.

6 This oral culture managed to travel through time but also through space. The existence of a common literature on both sides of the inners seas shows that the latter were not considered as a barrier, and that insularity did not necessarily mean isolation. Man sailed the seas even in the Bronze and Iron Ages. However rough and wild, the liquid element was part of Man's way of life; it compelled them to develop sailing techniques. ${ }^{11}$ If Deirdre's tale undertook the voyage, other stories did cross the inner seas between Ireland and Scotland as well, for example that of Diarmuid and Grainne. Belonging to the Irish Leinster Cycle, it is found in Scotland too, as J. Watson argued in his History of the Celtic Place Names of Scotland: "The Gael carried the tale of Diarmid to Scotland, locating the scene of his hunting of the boar and his tragic death in many parts of the North, as for instance at Beinn Laghail (Ben Loyal) in Sutherland, in Kintail of Ross-shire, in Brae Lochaber, and in Perthshire." (1993, p. 208) We have traced the contours of a literary territory, as it were. Within its boundaries, a water expanse unfolds: the inner seas.

On the following map, the coastal limits of the inner seas between Ireland and Scotland are colored in blue. The main places referred to in the tale are indicated. Such indications inform the importance of geographical elements within the tale. The map enables to understand how deeply rooted actual geographical locations are within Deirdre's story. Besides, it allows to realize that not only the territory involved in the tale comprises the area of the inner seas but also the land on both sides. This is where the "real" landscape merges with legend. ${ }^{12}$ In Ireland, the places are Emain Macha, the royal house of the king of Ulster, Conchubor (Cunnahar ${ }^{13}$ ) macNessa, Slieve Fuadh, 
house of Deirdre's nurse, Lavarcham (Lower'kem, as in allow), ${ }^{14}$ where Deirdre was brought up away from sight, and Uisneach, another royal site,$^{15}$ said to be the centre of Ireland, ${ }^{16}$ from which Naisi and his brothers, the sons of Uisneach, originated.

Figure 1. - The Inner Seas in Deirdre's Story, Geography of a Tale.

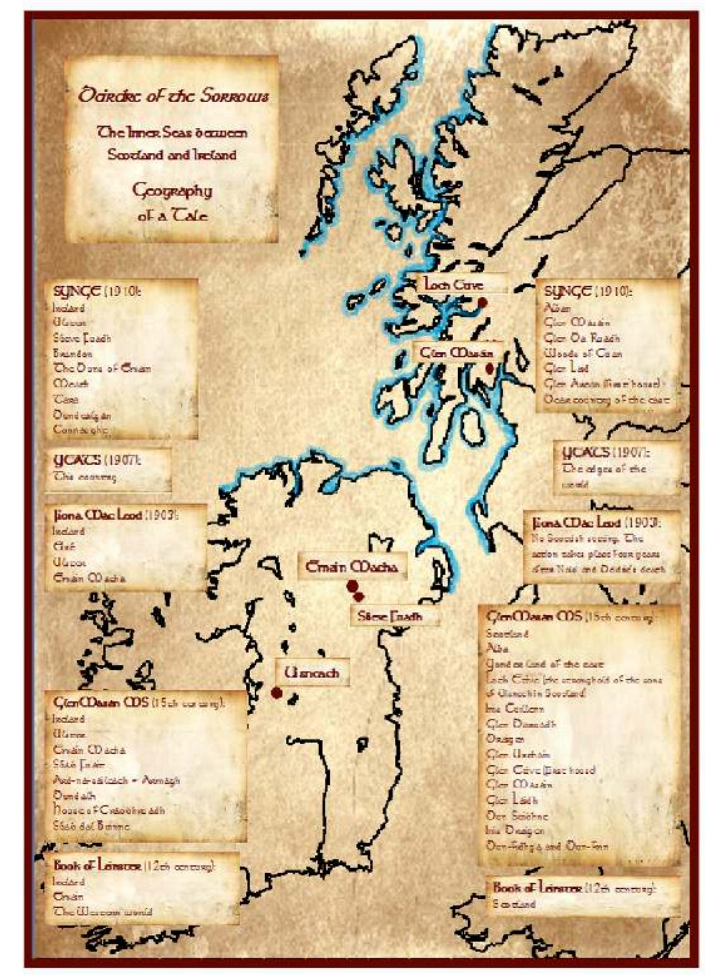

Map designed by Céline Savatier-Lahondès, from a blank map by Daniel Dalet, @ histgeo.ac-aixmarseille.fr, with kind authorization.

8 Here is how Uisneach was founded, according to the Suidigud Tellaig Temra [The Settling of the Manor of Tara]:

Then the nobles of Ireland came as we have related to accompany Fintan to Usnech, and they took leave of one another on the top of Usnech. And he set up in their presence a pillar-stone of five ridges on the summit of Usnech. And he assigned a ridge of it to every province in Ireland, for thus are Tara and Usnech in Ireland, as its two kidneys are in a beast. ${ }^{17}$

[...]

The points of the great provinces run towards Usnech, they have divided yonder stone through it into five. ${ }^{18}$

From a political as well as from a metaphorical perspective, it is important to consider Uisneach's central position, that of a symbolic heart, to which all the parts of the body of Eire converge. It gives an aura to the characters of the sons of Uisneach in the present tale. They are part of the Red Branch House of warriors, to which Cuchulainn also belongs. They embody the power and strength of Ireland. Their planned destruction, according to the prophecy, sounds like a myth of Apocalypse.

In Scotland, Loch Etive, Glen Masain and most of the places mentioned in the different versions are situated in Cowal, Argyllshire. It is the geographical position of the kingdom of Dalriata, which developed in Scotland from 5th century to 9th century AD It is to be noted that the 15th century version of the Glenmasan manuscript provides the 
highest number of place names in Scotland among the other versions, as if some emphasis had been purposely laid on the Scottish territory by the scribe who compiled the story, a version which may well have been in circulation orally before being committed to writing. The fact that more than ten Scottish place names are present in this manuscript is an indication of how well the tale was anchored on the Scottish side of the inner seas.

Let us now turn to the plot. In its full version, the story of Deirdre-her name is said to mean "alarm" (Hyde, 1895, p. 161)-starts off with a prophecy uttered by the druid Cathbad during a royal feast at Feidlimid's house. The latter is Deirdre's father and King Conchubor's storyteller. This is what happened, according to the oldest version:

The Ulstermen were drinking in the house of Feidlimid macDaill, the story-teller of Conchobor. Now the wife of Feidlimid was attending upon the host, standing up and she being pregnant. Drinking horns and portions [of food] circled around, and they uttered a drunken shout.

When they were about to go to bed, the woman came to her bed. While she was going across the middle of the house, the infant in her womb screamed so that it was heard throughout the whole enclosure. (Hull, 1949)

11 Then, to answer everybody's concern, Cathbad the "seer" said that inside Feidlimid's wife's womb was a woman of great beauty, a woman "for whom there will be many slaughters among the chariot-fighters of Ulster" (Hull, 1949). The warriors wanted to slay her but King Conchubor refused to have her killed and she was raised away from the world until she was old enough to become his queen. A few years later, just before her wedding with Conchubor, she met the Sons of Usna, Naisi (Nee'shi), Ainlé (Ainlă) and Ardan in the hills. By uttering a "geis", ${ }^{19}$ she compelled Naisi, the elder, to take her with him and flee to Scotland:

While, therefore, the aforesaid Noisiu was alone outside, she quickly stole out to him as if to go past him, and he did not recognize her. 'Fair,' he said, 'is the heifer that goes past me.' 'Heifers,' she said, 'are bound to be big where bulls are not wont to be.' 'You have the bull of the province,' he said, 'namely, the king of the Ulstermen.' 'I would choose between the two of you,' she said, 'and I would take a young bullock like you.' 'By no means!' he said. 'Even because of Cathbad's prophecy.' 'Do you say that in order to reject me?' 'It assuredly will be for that reason,' he said. Therewith she made a leap to him and grasped both ears on his head. 'These [are] two ears of shame and of derision,' she said, 'unless you take me away with you.' 'Go away from me, O woman,' he said. 'You shall have that,' she said. (Hull, 1949)

The persuading power of her voice prevented him from refusing since they eventually went to Scotland. They spent seven years there, some versions say sixteen years, and finally went back to Ireland, reassured by Conchubor's message of forgiveness brought to Scotland by Fergus, one of his most faithful warriors. Once back in Ireland, the brothers got killed, Deirdre committed suicide, a war followed, and with it the ruin of Emain Macha Deirdre of the Sorrows's genre oscillates between tragedy and epic poetry, in the modern sense of the terms, that is to say that ingredients belonging to both genres can be found in Synge's work. The play relates the downfall of a central character, Deirdre, and with her of the whole Red Branch of warriors. The latter are legendary heroes who accomplished great deeds. However, Deirdre's actions can also be seen as "actions of a heroic figure, whose deeds can change the future of a nation". ${ }^{20}$ Proinsias Mac Cana argues that "the heroic cycles relate political situations after they were overcome in actual history. We know that Emain Macha was destroyed probably at the beginning or toward the middle of the 5th century $\mathrm{AD}$, so that the founding facts 
of the stories which have reached us must have come from a more ancient although undetermined period" (Mac Cana, 1997, p. 679). Myth and history mingle in cycles where characters are heroes, close to semi gods sometimes, endowed with magical powers. Deirdre's voice is performative, that is to say that the words she utters have the power to implement her will. It takes the value of a "geis", in this case, an injunction, something Naisi cannot resist. The epic quality lies in the fact that Deirdre's character has the potential to change the course of actions, while paradoxically, she is at the origin of the fatal process announced by the prophecy. In this story, hamartia, to use Aristotle's definition of tragedy, is inherent to the main character. She was born with it. She has not accomplished any error herself. The play is a tragedy in the sense that it is "a dramatization of an individual's sense of life and society as constantly under threat from the arbitrary chances of fate and humanity's own innate savagery". ${ }^{21}$ The act of the heroes, the young, perfect "better than ourselves" characters, their fleet to Scotland, "opens a gap in the fragile fabric of morality and civilization through which the primeval forces of anarchy and destruction pour". ${ }^{22}$ They defy king Conchubor, thus provoking their downfall.

There are many modern versions of the story. They differ considerably, primarily in the choice of the episodes they tell. For instance, Scottish Fiona MacLeod (William Sharp) deals with the aftermath of the tragedy, once everybody is dead. Paradoxically, the Scottish author does not treat the characters' exile in Scotland. Is it because the focus was mainly on Ireland during the Celtic revival? Yet, there was a Scottish Gaelic renaissance too. Politics and national culture are strongly intertwined when related to the histories of the two countries at the end of the 19th and beginning of the 20th centuries. As Professor James Hunter, from the University of the Highlands and Islands argued in his article published in the Scottish Historical Review in 1975, "When, towards the end of the nineteenth century [...] in the Highlands and in Ireland, attempts were made to reform the agrarian order on the one hand and to revive and protect the Gaelic language on the other, it was almost inevitable that the two movements should come into contact". (1975, p. 180) According to James Hunter who cites Daly: "The young Douglas Hyde [poet and future president of the new Irish Republic] who toured the Highlands of Scotland in 1886 and found Gaelic there to be in a 'much healthier state than Irish is in Ireland' was to draw considerable inspiration from the Scottish Gaelic revival, particularly from the work of folklorists like John F. Campbell of Islay". ${ }^{23}$ Apparently, W. B. Yeats (1897) saw in Fiona MacLeod's tales an accomplishment of this Celtic cultural revival.

However, Scottish writers seem to have been contemplating and even admiring the booming Irish Cultural Renaissance in the first years of the twentieth century, without getting involved in such a resounding movement themselves. Part of the explanation comes from the fact that the social context was different. In 1918, Ruaraidh Erkine, the Scottish nationalist, political activist, writer and Scottish Gaelic language campaigner, put forward the absence of popular support in the movement in Scotland: "Hitherto, the Celtic movement in Scotland has not been a popular even less a democratic movement. It has divided its attentions between the lairdocracy on the one hand and the bourgeoisie on the other". (Hunter, 1975, p. 199) In the article previously referred to, Professor James Hunter claims that the economic context too was different: "Culturally, Scotland may have been a British colony. Socially and economically it was not. Insofar as Ireland-or India or Africa-was a victim of British imperialism that 
imperialism benefitted Scotland as much as England. Far from being a British colony, in other words, Scotland was an integral part of the imperial power". (1975, p. 204) While, as James Hunter explains, the parallel between the situations in the Scottish Highlands and Ireland was relevant, the similarity could not extend to the whole Scottish Nation (Hunter, 1975, p. 203). This proposition shows a discrepancy in the degree of urgency that existed in both countries as regards the expression of national identity. It might also explain why in today's polls, Scotland positions itself on a medium line between independence and remain. Nevertheless, at the time of the Irish revival, Scottish eyes were turned towards Ireland. Although he is concerned with politics, Hunter uses the word "obsession" to qualify the amount of attention granted to Ireland, especially at the time of the Easter Rising: "an obsession-and obsession is not too strong a wordwith Ireland" (Hunter, 1975, p. 198).

William Butler Yeats's Deirdre begins when the lovers set foot in Ireland, after their seven-year exile. He doesn't consider the Scottish episode either. The Irish setting only is granted a place, as if to lay the emphasis on Ireland itself, once again. Conversely, John Millington Synge's play opens when Deirdre, about to marry Conchubor, has just met Naisi and his brothers. Synge wrote a complete version, in which the plot is similar to that of the 12th century manuscript. So did George William Russel (A.E.) whose dramatic piece was written in 1902, before Synge's. Critic Michel Bariou points out their similar structure, arguing that the latter probably "borrowed the tripartite structure of Deirdre of the Sorrows to AE's play" ${ }^{24}$ (Bariou, 1990, p. 73). The drama unfolds in three acts, the first in Ireland, the second in Scotland and the last back in Ireland again. In Synge's version, Ireland is given much presence, even when the characters are away. It possesses a power of attraction. The land motif bears a strong emotional signature. Deirdre chants her attachment to her "dear country of the East" 25 before leaving Scotland. She expresses how strongly she will miss it. Yet, Ireland remains the place to which one must go back to: "It's a lonesome thing to be away from Ireland always" ${ }^{26}$, Deirdre says in act II. Considering the time of the writing, at the beginning of the twentieth century, this statement sounds like an homage paid to the Irish Diaspora, forced to emigrate from Ireland massively in the second half of the 19th century.

In act II, while Fergus is trying to convince Deirdre and Naisi to go back to Ireland with him, his words sound as a plea for the beauties of the island:

When I was a young man we'd have given a lifetime to be in Ireland a score of weeks, and to this day the old men have nothing so heavy as knowing it's in a short while they'll lose the high skies are over Ireland, and the lonesome mornings with birds crying on the bogs. Let you come this day for there's no place but Ireland where the Gael can have peace always. (Synge, 1968, p. 225)

However, beauty alone is not sufficient to qualify the author's style in the above statement. Its lyricism can be felt in Fergus's expression of intense longing for the land of the Gaels. Vivid images of the local landscapes-the "high skies", the "birds crying on the bogs"-convey Fergus's powerful yearning and seem to sing the beauties of the land along with the character. Yet, far from rendering a uniformly mellifluous sound, the lyrical property of the passage gives way to specific features, revealed in the peculiar rhythm of syncopated sentences: "they'll lose the high skies are over Ireland" vibrates according to the sea swell-irregular, sometimes brutal-which finishes its course washed up on the shores of Ireland. The bogs (line 4 in the extract above) are a common feature to Ireland and Scotland. In act II, Owen complains he has been "waiting three weeks getting ague and asthma in the chill of the bogs" (Synge, 1968, 
p. 221). Yet, Ireland only appears as the refuge of the "Gael" (last line in the extract above). In Deirdre's story, the shelter is Scotland. Ireland embodies the seat of all dangers and potential death. Yet, Fergus is on Conchubor's side. His interest is to bring the lovers back to Ireland. He extols the merits of his motherland and presents it as the ultimate home. Again, the focus on Ireland in the tale parallels the literary history of the time. The light is cast on a country that has undertaken its cultural identity awakening:

Depuis le 16janvier 1899, avec la fondation de l'Irish Literary Theatre par Yeats, un projet précis vise à donner au public des pièces nouvelles s'éloignant des conventions du théâtre commercial britannique et du répertoire shakespearien [...]. Mais, jusqu'en 1902, ce théâtre nouveau a souffert d'un vice majeur: pour représenter ses pièces, il doit faire appel à des compagnies britanniques dont la diction ne correspond pas aux exigences du texte ni aux impératifs esthétiques des auteurs, de Yeats en particulier. ${ }^{27}$ (Bariou, 1990, p. 67)

18 The project was carefully thought of and its objectives were well defined. Yeats encouraged the creation of an authentic expression. That is to say, he encouraged authors to use a specific language for their characters; a language that would resemble the Irish people's actual mode of expression. Synge tried to achieve this. René Agostini wrote: "Synge charrie toute une tradition orale des plus authentiques - un art, mieux, un artisanat $d u$ récit populaire [...]" ${ }^{28}$ (Agostini, 1992, p. 28). Not only is his style highly lyrical, in the sense that his characters sing the beauties of the land and sea in a deeply felt manner, but it also conveys a peculiarity which enabled him to be part of the group of the modern Irish dramatists. In one of his letters, Yeats said about Synge's play: “I think it would be impossible to any company except ours. I can't imagine anybody getting his peculiar rhythm without being personally instructed in it." ${ }^{29}$ Distinctiveness and identity lie in the very rhythm of the sentence itself. Despite the multiple revisions he did on Deirdre, Synge couldn't complete the play. Nevertheless, without any excess in the lyrical apparatus, his writing managed to let the oral tradition speak for itself. Although Synge was not as openly political as other Irish authors, like Sean O'Casey, for instance, it cannot be ignored that such a re-creation was used to boost the feelings that would lead to cultural independence.

The authors who undertook the rewriting of Deirdre's story were thus Irish and Scottish. In our attempt to map the authorial history of the tale, we can see that it is still present on both sides of the inner seas in the awakening of the modern era. The marine territory appears as a metacharacteristic of the tale, always present, deeply rooted in its landscape, part of its very inner and outer structure. Among the examples cited above, the sea actually appears in the general structure of the play in the versions by A.E. and Synge only. Deirdre, Naisi and his brothers sail the inner seas twice in seven years' time-first to reach their land of exile and secondly to go back to Ireland. The voyage occurs, to use a title belonging to Virginia Woolf, Between the Acts. ${ }^{30}$ The sea is not depicted as a major component of the story, yet it is present, and its "absent presence" (Pavis, 2002, p. 356, b) pervades Synge's play. It is necessarily absent from the physicality of the stage but the text creates its presence off stage, like the Channel crossing of Henry's fleet in Shakespeare's Henry V (1965 [1954], act III). This fictional device the exchange between text and staging in terms of presence and absence, is characteristic of drama in Pavis's words. It finds a particular application in Shakespeare's play. At the beginning of act III, the Chorus once more appeals to the spectator's imagination to conjure up images. After raging battles, it is question of sailing ships-Henry's fleet navigating to Harfleur. Here, the relationship between the 
text and the performance reaches the far end limit of drama proper, to stand on the brink of story-telling. In Synge's play, the motif of the sea itself is used to render the presence of an absence. Act one ends on Deirdre and Naisi's wedding celebrated by Ainle who invokes all the natural elements, among which the sea, to bless the couple: "May the air bless you, and water and the wind, the sea and all the hours of the sun and moon." (Synge, 1968, p. 215) This sounds as a pagan religious ritual in which the sea is included as a preeminent factor of the invisible action of the sacred.

Then, the curtain falls and opens again on the lovers in their Scottish dwelling. In act I, Naisi had imagined their stay in Scotland and had seen themselves "taking [their] journeys among the little islands in the sea" (Synge, 1968, p. 211). The imaginative work of the story-teller leads the audience on the dented shores of Western Scotland, as in a form of hypothyposis: "The stars are out Deirdre, and let you come with me quickly, for it is the stars will be our lamps many nights and we abroad in Alban, and taking our journeys among the little islands in the sea." (Ibid.) The account is short and so vivid that it virtually transports the heroes to the Scottish shores, in a flash that constitutes their first voyage. Then, after a seven-year period described as a complete blessing for the royal lovers and their train, act II ends on Deirdre's farewell to Scotland. She knows she is going to face death: "Woods of Cuan, woods of Cuan... It's seven years we've had a life was joy only and this day we're going west, this day we're facing death maybe, and death should be a poor untidy thing, though it's a queen that dies." (Ibid., p. 239) Epizeuxis (the repetition of "woods of Cuan") and aposiopesis (the unfinished sentence), both express Deirdre's troubled emotional state. Then, anadiplosis, or gradatio, achieved through the doubling of the word "death", shows the logics Deirdre's character is following. Her own death appears more and more certain to her the further her thoughts unfold. The idea is all the more pregnant in her mind as it is repeated under derived forms: "death" and "dies" to which "west" can be added as symbolical of death, being the setting place of the sun. Besides, the rhythm of the whole passage is syncopated. Firstly, one single sentence groups several opposed thoughts: the sevenyear period of joy and the looming death ahead. Secondly, the opposition in ideas is coupled with an unstable rhythm due to the missing conjunction "that." We are tempted to read "we've had a life [that] was joy only", or "only joy". The figure, anacoluthon, produces a rupture in the sentence structure. The smoothness brought by the linking word is absent. Thus, the effect created is that of a broken oral speech. Deirdre's agitated mind jostles the formal logics of speech. She operates an abrupt change. Uniformity and balance make way to instability and discord. Sentences are harshly disrupted, like boats on a raging sea.

21 The image of a dying queen, as Deirdre sees herself, announces an ill omen for the stability of the kingdom. Besides, the other world, the Sidh, in the Celtic mythology is situated beyond the sea, amongst other places (Guyonvarc'h \& Le Roux, 1986, p. 418). It is generally a woman of the Sid, "bansid" (in English, banshee) who comes and fetches a mortal, always a man, to take him to the land of eternal youth (ibid.). Deirdre could be seen as a banshee, taking her lover to the other world and enjoying everlasting life with him. Although the place where the lovers enjoyed life most is Alba, the latter cannot be considered as the Celtic paradise. The land of eternal youth, Tírnan óg, the Celtic other world offers to live the same life as the human one, even a happier one. In Synge's version, Deirdre feels the weight of time in Scotland. The magic of the land ceases after a few years spent there. Youth escapes the queen's grasp. Although she doesn't openly 
say it then, in act II the reader knows that Deirdre is aware of the prophecy. It is made clear in the first act, when Deirdre and Naisi meet for the first time:

Naisi: You are Feidlimid's daughter that Conchubor has walled up from all the men of Ulster?

Deirdre: Do many know what is foretold, that Deirdre will be the ruin of the Sons of Usna, and have a little grave by herself, and a story will be told forever? (Synge, 1968, p. 209)

The metanarrative statement emphasizes the weight of the prophecy which, right from the beginning of the play, oversteps the limits of the tale itself.

The argument Deirdre uses to leave her paradise is the fear of getting old. To Deirdre, dying young is better than slow decay (Synge, 1968, p. 237). In Ireland, both she and Naisi will meet their fates, but they will not see each other ageing. The contemplation of this outcome helps Deirdre decide to abide by Conchubor's will, to trust his benevolence and go back to Ireland, where she will confront death. Like Ossian, who left the land of eternal youth and aged as soon as he set foot on the ground, after crossing the sea on horseback, ${ }^{31}$ Deirdre and Naisi face the condition of mortals in Ireland. They leave their dwelling of the east, cross the sea-the passage-and set foot in another world, as it were. When act III opens, the setting is that of Emain Macha. King Conchubor awaits the two lovers. The sea has been, at the same time, holding a safe distance between them and the jealousy of Conchubor and maintaining a link between the two territories.

In Fiona MacLeod's version, the sons of Usna are "the noblest of all the Gaels of Eri and Alba" (1903, p. 32). One people for two territories separated by an expanse of sea-this is the mapping of what will become the kingdom of Dalriata, in the 6th century AD. The sea appears as a feature of interconnections between Scotland and Ireland. Deirdre and Naisi, queen and king with land possessions in Glen Etive, in some versions of the tale, can be seen as precursors of the Dalriatan sovereigns. Loch Etive is a sea loch which, in the story, serves as an umbilical cord linking the two countries as one, and enabling exchanges between them. In Synge's work, Lavarcham says "maybe [she]'ll be sailing back and forward on the seas to be looking at [Deirdre's] face" (Synge, 1968, p. 213). The nurse's wish is plainly to go and see Deirdre in Alba. Yet, a double image also shows here. The sea becomes a screen on which Deirdre's face is projected, or a mirror in which it is revealed. The use of the -ing forms, by focusing on the process, enables to visualize the voyage slowly unfolding, with the current and the waves. What the reader can conceive as being Lavarcham's thoughts appears in between the lines. Synge manages to let the invisible materialize, as in some magical conjuring. More pragmatically, the back and forth sea sailings also let us consider the ordeal that such an enterprise would represent.

In the second act, Owen claims one has to be mad to cross nine seas, "nine waves" he says, "after a fool's wife", to which Deirdre answers that he has lost his manners after leaving the royal Emain for too long (Synge, 1968, p. 221). These nine waves may refer to the nine water bodies of the inner seas: the Minch and Little Minch, the Sound of Harris, the Inner Sound, the Sea of the Hebrides, the Firth of Lorn, the Sound of Jura, the Firth of Clyde, Belfast Lough and the North Channel. Their names may have changed through time. The geographical reality covered by the "nine waves" may be a lot different too. Nevertheless, they evoke the numerous expanses of water a sailor had to go through to reach Scotland. Furthermore, sailing on a curagh ${ }^{32}$ represents a perilous adventure, even if the small boat moved by oars could face the open seas. 
Deirdre chooses to sail back to Ireland "when the tide turns on the sand" she says (Synge, 1968, p. 233). "With the tide in a little while we will be journeying again", she also declares (ibid., p. 229). The tidal motif informs the uncertain time and the risky adventure undertaken by the two heroes, Deirdre and Naisi. The wave's swaying back and forth evokes the questioning that takes place in act II between leaving and staying. Arguments are put forward, but eventually, Deirdre's will to face the inescapability of the prophecy prevails on Naisi's simple desire to grow old with her in Scotland, yet considered by both as an ideal place. She purposely chooses flying from paradise, a hazardous sailing and a promise of destruction.

Some have seen Deirdre as a weak character unable to stand on her own two feet without her husband. This sole idea has been interpreted as a motivation for suicide (Doyle, 1999, pp. 33-46). Yet, in the oldest version of the story, Deirdre confronts a violent death: she crashes her skull against a rock. This doesn't look like a sign of weakness. The episode is not present in Synge's or in Yeats's plays in which Deirdre "merely" stabs herself. However, both authors have revealed the character's strength. In both versions, it is the sea metaphor which helps convey the heroine's toughness. In Yeats's drama, Deirdre asserts that she is not like queen Edain who "had but the cold blood of the sea in her veins". ${ }^{33}$ Deirdre's veins are "hot", "[she has] not been born of the cold, haughty waves" (Yeats, 1934, p.190). In Synge's play, she says: "If Conchubor'll make me a queen, I'll have the right of a queen who is master, taking her own choice, and making a stir to the edges of the sea" (Synge, 1968, p. 199). The sea is used in two different ways. On the one hand, its coldness serves to emphasize the contrast with Deirdre's fiery temper. On the other hand, the water expanse materializes the extent of the queen's power. In both cases, Deirdre's character amplifies into the figure of a great queen. The sea turns into a metaphorical device enabling her to do so.

In MacLeod's The House of Usna, Duach, says of Cathbad's prophecy: “Ay: that before his eyes he saw a sea of blood, and saw it rise and rise till it overflowed great straths, and laved the flanks of high hills, and from the summits of the mountains poured down upon the lands of the Gael in a thundering flood, blood-red, to the blood-red sea." (MacLeod, 1903, p. 39) In this statement, the red sea does not open to let the elected people go. On the contrary, it is a sea of blood, flooding the countries of the Gael (Ireland and Scotland) and engulfing the warriors of the Red Branch, to which the Sons of Uisneach belong. Although it seems apparent, the Christian motif is absent from the symbolism chosen by MacLeod. Straths (wide glens) are flooded. The heroes of the tale cannot escape. They are not the chosen ones who will be saved by the Christian God. MacLeod may have used a Christian image to start with, but it is eventually distorted. The motif of the flood remains, which can be seen as a Christian undertone, but it is not treated in the same way as in the Bible. Besides, in Celtic mythology, there is no avenging or rewarding God. In Deirdre's story especially, the emphasis is laid on the capacity of the woman to take the lead as regards the clan's destiny. The heroes of the tale will meet their fates and the outcome will be deadly. The sea turns out to be a major symbolical element, suggesting looming peril. Once again, a concrete phenomenon (the sea is potentially mortal) is associated to myth. Nature proves a major source of inspiration for the epic. The tone is elevated and heroic. As in the Iliad, the heroes undertake a perilous voyage towards their fate. Although the sea image is prophetical rather than taking an actual part in the course of action, it remains this 
concrete, objective element which gives authority to the epic, according to Northrop Frye: "With the Iliad, once and for all an objective and disinterested element enters into the poet's vision of human life. With this element, [...] poetry acquires the authority that since the Iliad it has never lost, an authority based, like the authority of science, on the vision of nature as an impersonal order." (Childs \& Fowler, 2006, p. 70) This order is inexorable, it is part of the general pattern of the story, in which the fate of the characters appears as an inflexible combination of events. Deirdre is the epic heroin who leads her clan to their fate after a perilous voyage. However, the epic merges with the tragic when the sea takes the colour of blood. MacLeod's writing renders the ambient hazard and looming downfall with the use of diacope. Words are repeated at brief intervals: "rise and rise", "blood-red to the blood-red sea" creating an effect of deep, overwhelming emotion. The reader or the spectator cannot but be absorbed in the cleft created by the figure of speech. There is a break in the sentence rhythm together with an insistence on the image of the rising red sea. As a result, Cathbad's words destabilize and submerge at the same time. The effect is all encompassing.

Later in the play, Duach warns Conchubor who wants his son Cormac to rule after him: "Beware, O Concobar, of the foam of dreams. It is only the great wave that can lift Eiré." (MacLeod, 1903, p. 45) The tone has changed here, and the movement is different. Far from being feared, the wave seems to be expected. The word "lift" suggests a vertical movement as well as a major change. To lift a whole country, a great power must be at work. Deirdre can be seen as the wave that will change Ireland (and Scotland maybe) no matter what may come of it, even if war and bloodshed ensue. This can be interpreted as prefiguring the fight for the Irish independence from Britain, and the revival of Irish identity, which Scotland observed so closely. Therefore, the territory on both sides of the inner seas appears to be mapped according to the identity criterion as well.

The oxymoronic power of the sea suggests belonging and exile, bond and rupture, between the mythological past and modernity, between determinism and individualism, between fatality and freedom. In Synge's lyrical play, words flow, forming a unique territory between Ireland and Scotland. Water becomes an element of "the self-metamorphosis of a girl into a mythic queen or a heroine, the parable of an individual who accomplishes himself" (Agostini, 1992, p. 24). The inner seas may serve as a rite of passage for the self-accomplishment of a territory too. In that sense, the character of Deirdre stands as the metaphor of countries involved in a cultural revival, which experience the indomitable yearn for the expression of their proper voices. Authors, among whom Yeats especially, had ambitions (which he later revoked) of an international pan-Celtism. Both Scotland and Ireland had to draw on their ancient roots to reveal their present identity.

Thus, wandering the inner seas indicates a quest for meaning and identity. The number of modern rewritings of Deirdre's story shows how significant it was at the time of the Irish cultural revival. As we have seen, the myth seems to be inseparable from politics, on both sides of the inner seas. Scotland took a different route in her modern awakening but Ireland chose to meet her fate, as it were, however tragic. The fights for the independence of the country were recurrent and bloody. Yet, a renewal came from this will to confront the inevitable; the political status of the country changed. play. In his preface to Deirdre of the Sorrows, Yeats asserts that the drama paved the way 
to Synge's own end in the sense that it accompanied him: "[...] so much beauty is there in its course, and such wild nobleness in its end, and so poignant is an emotion and wisdom that were his own preparation for death." (Synge, 1968, p. 180) The beauty of the wilderness comes to mind and remains present as a major feature of the play. Especially, the strength of the inner seas resounds as a permanent echo to the ear. Sounds of an ancient past come ashore and inform the present. The waves beat the irregular tempo of the words. They know stories that involve men on both sides of the inner seas. They tell who these men and countries are.

\section{BIBLIOGRAPHY}

\section{Primary Sources}

BEST R. I. (ed. and trans.), 1910, Suidigud Tellaig Temra, The Settling of the Manor of Tara, from the Yellow Book of Lecan, col. 740-9 (end 14th-beginning 15th century) and the Book of Lismore, fol. 90a-92a (15th century), in Ériu, vol. 4, pp. 121-72. Available on <www.ucd.ie/tlh/trans/ rib.eriu.4.001.t.text.html>.

CoIMín Micheál, 1896, Laoi Oisin ar thír na n-óg: The Lay of Oisin in the Land of Youth, [AD 1750], with revised text, literal translation, new metrical version, notes and vocabulary, Dublin, Tomás ó Flannghaile (ed.).

HuLl Vernam (ed.), 1949, Longes mac n-Uislenn. The Exile of the Sons of Uisliu, [Reconstituted text based on the Book of Leinster MS, with introduction, translation, and notes], New York and London. Available on <www.ucc.ie/celt/published/T301020B/index.html>.

HYDE Douglas, 1895, The Three Sorrows of Story-telling and Ballads of Saint Columkille, London, T. Fisher Unwin.

MACLEOD Fiona, 1903, The House of Usna, Portland (Maine), Thomas B. Mosher, reproduced by Leopold classic Library.

SYNGE John Millington, 1968, Deirdre of the Sorrows, in Collected Works, Volume IV: Plays Book II, A. Saddlemyer (ed.), London, Oxford University Press.

SHAKESPEARE William, 1965, King Henry V [1954], J. H. Walter (ed.), London, Methuen.

YEATS William Butler, 1897, Review of Fiona MacLeod's Spiritual Tales, in The Sketch, 28 April.

YEATS William Butler, 1952, Deirdre, in The Collected Plays of W. B. Yeats [1934], London, MacMillan.

\section{Secondary Sources}

\section{Articles}

AGostini René, 1992, “À propos de Deirdre des douleurs”, in Deirdre, variations sur un mythe celtique, La Gacilly, Artus.

DoYLE Maria Elena, 1999, “A spindle for Battle: Feminism, Myth, and the Woman Nation in Irish Revival Drama”, Theatre Journal, vol. 51, The John Hopkins University Press, pp. 33-46. 
ERSKINE Ruaraidh, 1975, Guthna Bliadhna, XV [1918], in James Hunter, "The Gaelic Connection: The Highlands, Ireland and Nationalism: 1873-1922”, The Scottish Historical Review, vol. 54, no. 158, part 2, Edinburgh University Press, p. 99. Available on <www.jstor.org/stable/25529128> (consulted 18 September 2016).

HUNTER James, 1975, “The Gaelic Connection: The Highlands, Ireland and Nationalism: 18731922", The Scottish Historical Review, vol. 54, no. 158, part 2, Edinburgh University Press, p. 180. Available on <www.jstor.org/stable/25529128> (consulted 18 September 2016).

MACKINNON Donald, 1904, “The Glenmasan Manuscript, with Translation”, The Celtic Review, no. 1, Edinburgh.

NEWMAN Conor, 1998, "Reflections on the Making of a 'Royal Site' in Early Ireland”, World Archaeology, vol. 30, no. 1 (The Past in the Past: The Reuse of Ancient Monuments), Taylor \& Francis, pp. 127-41.

\section{Books and dictionaries}

BALDICK Chris, 2004, The Oxford Concise Dictionary of Literary Terms [1996], Oxford, New York. BARIOU Michel, 1990, Deirdre et la renaissance celtique, La Gacilly, Artus.

CHILDS Peter \& FoWLER Roger, 2006, The Routledge Dictionary of Literary Terms, based on A Dictionary of Modern Critical Terms [1973], edited by Roger Fowler, London and New York, Routledge.

DALY Dominic, 1974, The Young Douglas Hyde: The Dawn of the Irish Revolution and Renaissance, 18741893, Rowman \& Littlefield Publishers.

GRELLET Françoise, 1996, A Handbook of Literary Terms, Paris, Hachette.

GUYONVARC'H Christian \& LE Roux Françoise, 1986, Les Druides, Rennes, Ouest-France Université.

Mac CANA Proinsias, 1997, Les Celtes [1991], Sabatino Moscati, Otto Hermann Frey, Venceslas Kruta, Barry Raftery, Miklós Szabó (eds), Paris, Stock.

MACKINNON Donald, 1912, A Descriptive Catalogue of Gaelic Manuscripts in the Advocates' Library, Edinburgh, and Elsewhere in Scotland, Edinburgh.

PAVIS Patrice, 2002, Dictionnaire du théâtre, Paris, Armand Colin.

WATSON William J., 1993, The History of the Celtic Place-Names of Scotland [1926], Edinburgh and London, reprinted by Birlinn, Edinburgh.

\section{NOTES}

1. In order to provide a certain reading comfort, the proper nouns have been transcribed within brackets. The pronunciation here advised cannot be but approximate. An accurate pronunciation indication would require a proper phonetic transcription.

2. "Glossary and Guide to Pronunciation" in Synge (1968, p. XXXv).

3. Ibid.

4. <www.vanhamel.nl/codecs/Oidheadh_chloinne_Lir>.

5. D. Hyde, The Three Sorrows of Story-telling and Ballads of Saint Columkille, T. Fisher Unwin, London, 1895, p. 149. Columkille is one of the successors of the Abbey of Iona situated in Scotland. Once again, in a single book, although written in the 19th century, Scotland and Ireland saddle across the Inner Seas. 
6. "Glossary and Guide to Pronunciation" in Synge (1968).

7. Ibid.

8. "The Greek tragic hero gets lost precisely by struggling to escape a determinism he cannot avoid because it haunts him and sticks to him. The Celtic hero puts so much more passion and determination into what he is living as he knows or guesses about his destiny. Deirdre chooses to meet her destiny, she "provokes it"'. [My translation]

9. Dublin, Trinity College Library, 1339 olim H. 2.18 al. Book of Leinster, pp. 259b-261b; 12th century (oldest version). Dublin, Trinity College Library, 1318 olim H. 2.16 al. Yellow Book of Lecan, col. 749-53; 14th century.

10. Edinburgh, National Library of Scotland, MS 72.2.3 (Advocates Library, MS 53, Scottish Collection), 15th century, vellum, 27 leaves, of whom 25 folios are fully written upon, in 101 consecutively numbered columns; the outer two leaves cover the MS. (For details see Mackinnon, 1912, pp. 158-62.)

11. The curragh or currach, small boat moved by oars, was able to sail the high seas, despite of its simple making: "A small boat made of wickerwork covered with hides, used from ancient times in Scotland and Ireland; a coracle." (OED online)

12. The points on the map show the approximate locations of places according to their actual archeological settings. The placement on the map was made visually. It is meant to give an idea of the locations referred to in the tale and is by no means a hundred percent geographically accurate document. The situation on the map of the place where Deirdre was brought up, Slieve Fuadh, is more of a guess work than anything else. There is a place by that name situated near Newtown Hamilton (County Armagh). Since it is not far from Emain Macha, the site was accepted for the present research. It would need further inquiry, provided we could actually find something satisfactory.

13. "Glossary and Guide to Pronunciation" in Synge (1968).

14. Ibid.

15. "The Royal sites [...] were all sites of major royal inauguration, ceremony and assembly, representing each of the four Irish provinces: Ulster, Leinster, Munster and Connaught, as well as the region of Meath. Navan Fort is portrayed as the royal site for the kings of Ulster; Dún Ailinne for the kings of Leinster; Cashel for the kings of Munster and Rathcroghan for the kings of Connaught. Tara was the seat of the kings of Meath and the seat of the Irish high kings. In addition the Hill of Uisneach is traditionally the epicenter (navel) of Ireland, where the five provinces met. The sites are strongly linked to myth and legend and are associated with the transformation of Ireland from paganism to Christianity and Saint Patrick." (<http:// whc.unesco.org/en/tentativelists/5528/>)

16. "There are five celebrated royal sites in ancient Ireland, Teamhair, Cruiachain, Emain Macha, Dun Ailinne and Caisel, all since identified with extant archaeological monuments and complexes, namely Tara (Co. Meath) [...], Rathcroghan (Co. Roscommon), Navan Fort (Co. Armagh), Knockaulin (Co. Kildare) and Cashel (Co. Tipperary), with a sixth, Uisneach (Co. Westmeath), described in some sources as the umbilical centre of Ireland, the meeting place of the five provinces, a royal site in its own right, with traditions of druidical fire ceremony (Byrne 1973)." (Newman, 1998, pp. 127-41)

17. Best (1910): <www.ucd.ie/tlh/trans/rib.eriu.4.001.t.text.html>, stanza 32.

18. Ibid., stanza 33.

19. “Geis, pluriel geasa: «injonction, obligation, interdit» [...]. Le sens initial est celui d'une "incantation " basée sur le pouvoir de la parole vivante, inscrit dans l'étymologie de guidid « il prie » et de gûth «voix». La traduction de geis par «tabou» est à proscrire: le tabou n'est pas une notion indoeuropéenne et son aspect uniquement négatif est en contradiction avec le sens souvent positif du mot irlandais." [Gais, plural geasa: "injunction, obligation, interdiction" [...]. The original meaning is that of an "incantation" based on the power of the living word, as it is inscribed in the etymology 
of guidid "he prays" and gûth "voice". The translation of geis by "taboo" is to be proscribed: the taboo is not an Indo-European notion and its purely negative aspect is in contradiction with the often positive meaning of the Irish word]". (Guyonvarc'h \& Le Roux, 1986, p. 394) [English translation is mine.]

20. Definition of an epic/heroic poem, in Grellet (1996, p. 36).

21. Definition of "tragedy" in Childs \& Fowler (2006, p. 241).

22. Ibid.

23. Daly (1974, pp. 78-81, 105-6) qtd in Hunter (1975, p. 183).

24. "Synge, quant à lui a probablement emprunté la division tripartite de Deirdre of the Sorrows à la pièce de $A E$ ".

25. Synge (1968, p. 238). As it is noted, "dear country of the east" is a variation in the version of Deirdre's last speech in the second act as it is printed in the Cuala and Maunsel editions.

26. Ibid., p. 237.

27. "Since 16th January 1899, with the foundation of the Irish Literary Theatre by Yeats, a precise project aims to give new plays to the public, going away from the conventions of commercial British drama and the Shakespearean repertory. But up to 1902, this theatre suffered from a major flaw which is the obligation to appeal to British companies to stage its plays. However, their diction neither corresponds to the requirements of the text nor to the aesthetic needs of the authors, of Yeats in particular." [My translation]

28. "Synge drags along a whole oral tradition of the most authentic popular tale telling-an art, better a craft." [My translation]

29. Letter to John Quinn, 27 April 1908, The Letters of W. B. Yeats, ed. Allan Wade, p. 150, in Synge (1968, p. 179).

30. Between the Acts is Virginia Woolf's last novel. It was published posthumously in 1941.

31. M. Coimín, Laoi Oisin ar thír na n-óg: The Lay of Oisin in the Land of Youth (AD 1750), with revised text, literal translation, new metrical version, notes and vocabulary, Dublin, Tomás Ó Flannghaile (ed.), 1896. <http://catalogue.nli.ie/Record/vtls000138819>.

32. "Whose curagh is rowing from Ulster? I saw the oars through the tops of the trees", in Synge (1968, p. 217).

33. Deirdre's words, in Yeats (1952, p. 192).

\section{ABSTRACTS}

From

the

ancient story preserved in the 12th century Book of Leinster to 20th century versions, Longes mac nUislenn (The Exile of the Sons of Usnach) has been told and retold. It is a story of travel from Ireland to Scotland and back to Ireland again after seven years of exile. Deirdre of the Sorrows (1909) is John Millington Synge's highly lyrical version. It adds a philosophical aspect to the myth and deals with Irish identity, at a time when the Celtic Revival was strongly expressed by artists. In the

awakening of the Modern era, the story was rewritten by Irish authors, Synge and William Butler Yeats, as well as by a Scottish writer, Fiona McLeod (William Sharp). Thus, not only is the area of the seas present within the story of Deirdre itself, but also it appears to be an important feature in 
the mapping of the authorial history of the tale, as a metacharacteristic, imbedded, deeply rooted, always present. This paper aims to show that it plays an essential part in a story which has become, through the ages, a quest for meaning and identity.

Depuis le récit datant $\mathrm{du} \mathrm{XII}^{\mathrm{e}}$ siècle, conservé dans le Livre de Leinster, jusqu'aux versions modernes, Longes mac nUislenn (L'Exil des fils d'Usnach), a été maintes fois raconté. C'est une histoire de voyage, de l'Irlande vers l'Écosse, puis vers l'Irlande à nouveau, après un exil de sept années. Deirdre des douleurs(1909) est la version de John Millington Synge. D'une beauté lyrique, cette pièce ajoute un aspect philosophique au mythe. Elle traite de l'identité irlandaise, en une période où le renouveau celtique était fortement exprimé par les artistes. À l'aube de l'ère moderne, l'histoire a été beaucoup réécrite par

auteurs irlandais, Synge et William Butler Yeats notamment, mais aussi par un auteur écossais, Fiona MacLeod (William Sharp). Ainsi, non seulement la zone des mers intérieures est-elle présente dans l'histoire de Deirdre elle-même, mais elle apparaît aussi comme un trait important de la cartographie de l'histoire auctoriale $\mathrm{du}$ conte, telle une métacharactéristique, intrinsèque à l'histoire, profondément présente. Cet article souhaite montrer que les mers intérieures jouent un rôle important dans une histoire qui est devenue, au fil du temps, une quête de sens et d'identité.

\section{INDEX}

Keywords: the sea, link

and rupture, exile, identity

Mots-clés: la mer, lien et rupture, exil, identité

\section{AUTHOR}

\section{CÉLINE SAVATIER-LAHONDÈS}

Université Clermont Auvergne, IRHIM-UMR 5317 CNRS.

University of Stirling, Scotland, United Kingdom.

Céline Savatier-Lahondès is a fourth year PhD student, working under the joint supervision of Professor Danièle Berton from the University of Clermont-Auvergne (France), and Professor John Drakakis, from the University of Stirling (UK). She is also an "agrégée" secondary school English teacher in France. Her research center is IRHIM Clermont, CNRS, UMR 5317. She has already had the opportunity to communicate elements of her research in conferences in France and in Ireland. Apart from this one in Études écossaises, two of her articles have been recently accepted for publication: eCrini, in Nantes, on "Debt and Indebtedness in Medieval Texts" and Notes and Queries, Oxford (UK), on the walking forest in Shakespeare's Macbeth. These articles are expected to be published between March and June 2017. 